\title{
Textural properties of Köftür, a fruit based dessert
}

\author{
Kâmil Emre GERÇEKASLAN ${ }^{1 *}$ (D), Nesimi AKTAŞ ${ }^{1}$
}

\begin{abstract}
Köftür, a fruit-based dessert in Turkey, produces from partially concentrated grape juice and wheat flour. The aim of this study was to determine some physicochemical (moisture content, $\mathrm{pH}, \mathrm{a}_{\mathrm{w}}$, colour,) and textural properties (hardness, adhesiveness, cohesiveness, springiness, chewiness, gumminess, resilience) of this product during 3 months of storage. Water activity and colour values $\left(\mathrm{L}^{*}, \mathrm{a}^{*}, \mathrm{~b}^{*}\right)$ significantly increased $(\mathrm{p}<0.05)$, while moisture content and $\mathrm{pH}$ values significantly decreased $(\mathrm{p}<0.05)$ with storage time. Textural properties of köftür samples were significantly $(\mathrm{p}<0.05)$ changed at the end of the 3 -month storage period. It was determined that the increase in the shearing, penetration and TPA hardness values and the decrease in the adhesiveness, cohesiveness and resilience values of the köftür samples. As a result, it was concluded that the köftür preserves its textural properties during storage period.
\end{abstract}

Keywords: textural properties; storage; köftür; fruit based dessert.

Practical Application: The data obtained from study will be guiding the improvement of the storage conditions of the köftür like desserts.

\section{Introduction}

Turkey which is one of the major grape producing countries is the sixth-largest grape producer in the world (Food and Agriculture Organization, 2019). Due to ideal climatic conditions, grape producing is an important income source for many farmers across the country (Semerci et al., 2015). Approximately the half of the grapes produced in Turkey is table grape, $38 \%$ is for raisins and $12 \%$ is for wine production (Turkish Statistical Institute, 2019). Grapes are considered as easily perishable fruits and their nutritional value decreases during storage (Ali et al., 2016). Therefore, there has been a great trend to process grapes to various products such as wine, vinegar, grape leather, grape molasses and köftür.

Köftür is widely produced in autumn and consumed during winter season. The production of köftür starts with the boiling of grape juice (also called as şıra). When the boiled grape juice is concentrated and become partial molasses, wheat flour is added and mixed together. The product which is thickened by the addition of flour is poured on metal or wooden trays to form a layer of approximately $2 \mathrm{~cm}$ thick. It is allowed to cool in a cool place. The cooled köftür solidifies. The solidified köftür is cut into small pieces in desired shape (especially square or diamond). The köftür pieces are aligned on a clean cloth. It is left to dry under the sun. The dried köftür pieces are filled in a cruse and then sealed cruses are stored in a cool and dry place. During this storage process the sugared shell layer formed on the surface of the köftür samples. The köftür pieces are stored in this way for approximately 3 months and consumed during winter.

Köftür maintains its edible quality during storage period. However, to the best of our knowledge, there is no study conducted on the changes in the köftür occurring during storage. The present study aimed to determine the changes in some physicochemical and textural properties of köftür samples during the 3 months' storage period.

\section{Material and methods}

\subsection{Material}

Köftür samples were obtained from a local supplier (Bahtiyar Doğan Food Ind.Trade.Co.Ltd.) in Nevşehir, Turkey. Köftür samples were kept in a cold storage room at $10 \pm 2{ }^{\circ} \mathrm{C}$ for 3 months.

\subsection{Methods}

Determination of moisture content, $p H, a_{w}$ and colour of köftür samples

The moisture contents of the samples were determined gravimetrically by drying method in an air convection oven (JSOF-050, JSR, Korea) at $70{ }^{\circ} \mathrm{C}$ until a constant weight was achieved. The $\mathrm{pH}$ values of köftür samples were determined by blending $5 \mathrm{~g}$ of köftür samples with $50 \mathrm{ml}$ distilled water for $30 \mathrm{~s}$ by an Ultra Turrax homogenizer (MS-HS320, MTops) and then $\mathrm{pH}$ measurements were performed by a $\mathrm{pH}$ meter (Gondo PL-700-pv, Taiwan). The water activity values of samples were measured at $25^{\circ} \mathrm{C}$ using an $\mathrm{a}_{\mathrm{w}}$-meter (LabMaster-aw, Novasina, Switzerland). Colour values of samples were measured using a Minolta CR- 400 Chroma Meter (Konica Minolta Optics Inc, Japan). The colour values were expressed in CIE $\mathrm{L}^{*}, \mathrm{a}^{*}$ and $\mathrm{b}^{*}$ colour space as $L$ (lightness), $a$ (redness) and $b$ (yellowness). 


\section{Texture analysis}

Texture Profile Analysis, mainly penetration and shearing tests, of köftür samples were performed using TA.XT plus Texture Analyzer (Stable Micro Systems Ltd., Godalming, Surrey, UK) as follows. Köftür samples $\left(20^{\star} 10^{\star} 20 \mathrm{~mm}\right)$ were compressed to $30 \%$ with a $100 \mathrm{~mm}$ diameter compression plate $(\mathrm{P} / 100)$ for texture profile analysis (TPA) at following test procedure: test speed: $5 \mathrm{~mm} / \mathrm{s}$, trigger force: $30 \mathrm{~g}$-auto, time: $5 \mathrm{~s}$. Hardness, springiness, cohesiveness, gumminess, chewiness and resilience values were calculated from the TPA curve. Köftür samples (15 mm thickness) were punctured with a $2 \mathrm{~mm}$ diameter cylinder probe $(\mathrm{P} / 2)$ for penetration test under following conditions: test speed: $2 \mathrm{~mm} / \mathrm{s}$, post-test speed: $10 \mathrm{~mm} / \mathrm{s}$, trigger force: 20 g-auto, strain: $50 \%$. Hardness $(N)$ and stickiness $(N)$ values were calculated from the penetration test curve. Köftür samples $\left(10^{\star} 10^{\star} 30 \mathrm{~mm}\right)$ were cut by blade set (guillotine blade) for shearing test under following conditions: test speed: $2 \mathrm{~mm} / \mathrm{s}$, trigger force: $10 \mathrm{~g}$-auto, strain: $150 \%$. Hardness $(N)$ value was calculated from the shearing test curve. All the texture values were calculated by using the software (Texture Exponent 32, Stable Micro Systems Ltd., Godalming, Surrey, UK).

\section{Statistical analysis}

All the tests in the study were carried out in triplicate and the results were reported as mean \pm standard deviation. The acquired data were subjected to analysis of variance (ANOVA) by using SPSS 22.0 (IBM Corp., Armonk, NY, USA) package program, and the average values of meaningful main variance sources were compared with Duncan's multiple comparison test $(\mathrm{p}<0.05)$.

\section{Results}

\subsection{Moisture content, $\mathrm{pH}, \mathrm{a}_{w}$ and colour of köftür samples}

Changes in moisture content, $\mathrm{pH}, \mathrm{a}_{\mathrm{w}}$ and colour values of the köftür samples during storage were given in Table 1 . Water activity and colour values $\left(L^{*}, a^{*}, b^{*}\right)$ were significantly increased $(\mathrm{p}<0.05)$, while moisture content and $\mathrm{pH}$ values were significantly decreased $(\mathrm{p}<0.05)$ with increasing storage time. The moisture contents of köftür samples were decreased from $33.96 \%$ to $29.38 \%$ at the end of the first month and after then this value almost remained unchanged.

A significant decrease $(\mathrm{p}<0.05)$ was observed in $\mathrm{pH}$ value of the köftür samples only for the first month of storage. However, no change was observed in the $\mathrm{pH}$ value in the second and third months of storage. The water activity $\left(\mathrm{a}_{\mathrm{w}}\right)$ value of köftür samples was increased from 0.772 to 0.791 at the end of storage. The $\mathrm{L}^{*}$, $a^{\star}$ and $b^{\star}$ values of köftür samples were slightly but significantly increased as increases storage time. The $\mathrm{L}^{*}, \mathrm{a}^{\star}$ and $\mathrm{b}^{\star}$ values was increased from 25.89 to $26.61 ; 1.56$ to 1.84 and 6.42 to 7.18 , respectively.

\subsection{Textural properties of köftür samples}

The results of the shearing and penetration tests of the köftür samples were given in Table 2. A significant increase $(\mathrm{p}<0.05)$ in the hardness values of the shearing (from 16.84 to $18.61 \mathrm{~N}$ ) and penetration (from 1.81 to $2.04 \mathrm{~N}$ ) was determined with storage period. While these increases were statistically significant $(p<0.05)$ for both tests at the end of first month of storage, they were statistically insignificant $(p>0.05)$ at the end of second and third month of storage. Adhesiveness value of köftür samples was significantly $(\mathrm{p}<0.01)$ decreased from 0.85 to $0.69 \mathrm{~N}$.

The data obtained from texture profile analysis were slightly changed during storage (Table 3 ). While these changes were statistically significant $(\mathrm{p}<0.05)$ for hardness, cohesiveness and resilience values; they were statistically insignificant $(p>0.05)$ for springiness, gumminess and chewiness values. Hardness value was increased from 79.61 to $84.36 \mathrm{~N}$ at the end of first month of storage. While there were no statistically significant changes in hardness values at the end of first and second month of storage, a significant increase was observed in hardness value

Table 1. Moisture content, $\mathrm{pH}$, water activity and colour of köftür samples (mean $\pm \mathrm{SD})^{\mathrm{a}}$.

\begin{tabular}{|c|c|c|c|c|c|c|}
\hline \multirow{2}{*}{ Storage (month) } & \multirow{2}{*}{$\begin{array}{c}\text { Moisture content } \\
(\%)\end{array}$} & \multirow{2}{*}{$\mathrm{pH}$} & \multirow[b]{2}{*}{$\mathrm{a}_{\mathrm{w}}$} & \multicolumn{3}{|c|}{ Colour } \\
\hline & & & & $L$ & $+\mathrm{a}$ & $+\mathrm{b}$ \\
\hline 0 & $33.96 \pm 0.13 a$ & $6.09 \pm 0.04 a$ & $0.772 \pm 0.001 \mathrm{c}$ & $25.89 \pm 0.22 b$ & $1.56 \pm 0.02 c$ & $6.42 \pm 0.06 \mathrm{~d}$ \\
\hline 1 & $29.38 \pm 0.05 d$ & $6.04 \pm 0.01 b$ & $0.777 \pm 0.001 b$ & $26.21 \pm 0.36 \mathrm{ab}$ & $1.73 \pm 0.05 b$ & $6.79 \pm 0.05 c$ \\
\hline 2 & $30.11 \pm 0.09 b$ & $6.04 \pm 0.01 b$ & $0.777 \pm 0.001 b$ & $26.24 \pm 0.04 \mathrm{ab}$ & $1.86 \pm 0.07 \mathrm{a}$ & $6.95 \pm 0.06 \mathrm{~b}$ \\
\hline 3 & $29.73 \pm 0.12 c$ & $6.04 \pm 0.01 b$ & $0.791 \pm 0.001 \mathrm{a}$ & $26.61 \pm 0.19 \mathrm{a}$ & $1.84 \pm 0.02 \mathrm{a}$ & $7.18 \pm 0.06 \mathrm{a}$ \\
\hline$p$ & $* *$ & * & $* *$ & * & $* *$ & $* *$ \\
\hline
\end{tabular}

${ }^{a}$ Mean values with same letters in the same column are not statistically different, ${ }^{*} \mathrm{p}<0.05 ;{ }^{\star *} \mathrm{p}<0.01$.

Table 2. Shearing and penetration tests results of köftür samples (mean $\pm \mathrm{SD})^{\mathrm{a}}$.

\begin{tabular}{|c|c|c|c|}
\hline \multirow{2}{*}{ Storage (month) } & \multirow{2}{*}{$\begin{array}{c}\text { Shearing } \\
\text { Hardness }(N)\end{array}$} & \multicolumn{2}{|c|}{ Penetration } \\
\hline & & Hardness $(N)$ & Adhesiveness $(N)$ \\
\hline 0 & $16.84 \pm 0.46 b$ & $1.81 \pm 0.02 b$ & $0.85 \pm 0.02 \mathrm{a}$ \\
\hline 1 & $18.28 \pm 0.63 a$ & $2.02 \pm 0.01 \mathrm{a}$ & $0.84 \pm 0.02 \mathrm{a}$ \\
\hline 2 & $18.25 \pm 0.54 \mathrm{a}$ & $2.03 \pm 0.07 a$ & $0.74 \pm 0.01 b$ \\
\hline 3 & $18.61 \pm 0.34 a$ & $2.04 \pm 0.07 a$ & $0.69 \pm 0.02 c$ \\
\hline$p$ & * & $* *$ & $* *$ \\
\hline
\end{tabular}

${ }^{a}$ Mean values with same letters in the same column are not statistically different, ${ }^{*} \mathrm{p}<0.05 ;{ }^{* *} \mathrm{p}<0.01$. 
at the end of storage period. Cohesiveness and resilience values were decreased from 0.879 to 0.867 and 0.60 to 0.58 , respectively.

\subsection{Correlation coefficients}

Pearson's correlation coefficients between moisture content, $\mathrm{pH}, \mathrm{a}_{\mathrm{w}}$ and textural parameters were given in Table 4 . The $\mathrm{a}_{\mathrm{w}}$ value was correlated with shear hardness ( $\mathrm{r}=0.615)$, TPA hardness $(r=0.614)$, adhesiveness $(r=-0.808)$, cohesiveness $(r=-0.685)$ and resilience values $(r=-0.593)$. The moisture content was positively correlated with $\mathrm{pH}(\mathrm{r}=0.784)$, cohesiveness $(\mathrm{r}=0.693)$ and resilience values $(\mathrm{r}=0.729)$, while it was negatively correlated with shear hardness $(r=0.840)$, penetration hardness $(r=0.916)$ and TPA hardness values $(\mathrm{r}=0.585)$. While the penetration hardness was only correlated with cohesiveness $(r=-0.658)$ and resilience values $(r=-0.693)$; the shear hardness value was correlated with all TPA values except adhesiveness.

\section{Discussions}

\subsection{Moisture content, $\mathrm{pH}, \mathrm{a}_{w}$ and colour of köftür samples}

During the first month of storage, a layer of sugar is formed on the surface of the köftür. It was thought that this layer prevented the excessive loss of moisture content of the köftür in later periods of storage.

While the moisture content of the samples was slightly decreased, it was determined that the water activity value was increased. Since it contains starch, wheat flour is used in the production of köftür for thicken the syrup and to form a gel consistency. When heated in excess water, starch granule becomes hydrated, swells and causes an increase in viscosity. At this stage, semi-crystalline structure of the starch granule undergoes a change from an ordered to a disordered structure. This phenomenon is known as gelatinisation (Alishahi et al., 2015; Bogracheva et al., 2002; Vamadevan \& Bertoft, 2018). This disordered structure in gelatinised starch becomes ordered again in course of time. This phenomenon is defined as re-crystallisation or retrogradation (Wang et al., 2015). Starch granule exhibits two types of crystalline pattern, namely A and B (Bogracheva et al., 2002; Geera et al., 2006; Wang et al., 2015). Bogracheva et al. (2002) stated that the water trapped within the A-type crystalline structure has very low mobility, whereas B-type have both trapped water with low mobility and "weakly bound" water with higher mobility. Type A or B crystalline structure in native starches transformed B-type by starch retrogradation (Wang et al., 2015). The increase in water activity during storage (Table 1) might be associated with the increase in the amount of water released at the molecular state, because of the starch retgrogradation and the B-type crystalline structure have weakly bound water.

The increase in the $\mathrm{L}^{*}$ value of the köftür samples might be related to the recrystallization of starch. Retrogradation of starch causes an increase in opacity (Abba et al., 2014; Horstmann et al., 2017). Consequently, the increase in $L^{*}$ value could be explained

Table 3. Texture Profile Analysis test results of köftür samples (mean \pm SD)a.

\begin{tabular}{ccccccc}
\hline \multirow{2}{*}{ Storage (month) } & \multicolumn{5}{c}{ Texture Profile Analysis } \\
\cline { 2 - 7 } & Hardness $(N)$ & Springiness & Cohesiveness & Gumminess $(N)$ & Chewiness $(N)$ & Resilience \\
\hline 0 & $79,61 \pm 3,08 \mathrm{~b}$ & $0.992 \pm 0.000$ & $0.879 \pm 0.006 \mathrm{a}$ & $69,95 \pm 2,51$ & $69,39 \pm 2,49$ & $0.60 \pm 0.01 \mathrm{a}$ \\
1 & $84,36 \pm 6,38 \mathrm{ab}$ & $0.992 \pm 0.001$ & $0.873 \pm 0.002 \mathrm{ab}$ & $73,67 \pm 5,45$ & $73,05 \pm 5,36$ & $0.59 \pm 0.01 \mathrm{~b}$ \\
2 & $83,43 \pm 1,35 \mathrm{ab}$ & $0.989 \pm 0.003$ & $0.870 \pm 0.003 \mathrm{~b}$ & $72,58 \pm 1,09$ & $71,75 \pm 0,85$ & $0.59 \pm 0.01 \mathrm{~b}$ \\
3 & $87,45 \pm 2,36 \mathrm{a}$ & $0.989 \pm 0.003$ & $0.867 \pm 0.003 \mathrm{~b}$ & $75,85 \pm 1,83$ & $75,01 \pm 1,54$ & $0.58 \pm 0.01 \mathrm{~b}$ \\
$\mathrm{P}$ & $\star$ & $\mathrm{NS}$ & $*$ & $\mathrm{NS}$ & $\mathrm{NS}$ & $\star$ \\
\hline
\end{tabular}

${ }^{a}$ Mean values with same letters in the same column are not statistically different, NS: not significant; ${ }^{*} \mathrm{p}<0.05$.

Table 4. Pearson correlation coefficients between storage, aw, moisture content, $\mathrm{pH}$ and textural parameters.

\begin{tabular}{|c|c|c|c|c|c|c|c|c|c|c|c|}
\hline & 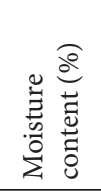 & $\stackrel{T}{2}$ & 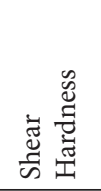 & 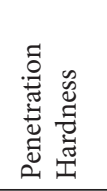 & 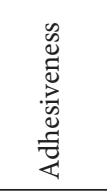 & 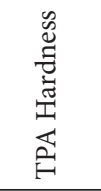 & 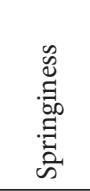 & 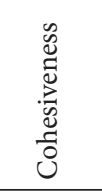 & 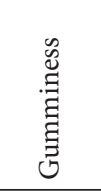 & 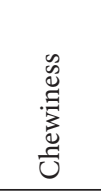 & 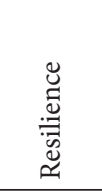 \\
\hline$a_{w}$ &,- 559 &,- 485 &, $615^{\star}$ & 571 &,$- 808^{\star *}$ &, $614^{*}$ &,- 349 &,$- 685^{\star}$ &, 580 & ,574 &,$- 593^{\star}$ \\
\hline Moisture content (\%) & - &, $784^{* *}$ &,$- 840^{\star *}$ &,$- 916^{* *}$ & ,476 &,$- 585^{*}$ & 310 &, $693^{*}$ &,- 550 &,- 546 &, $729^{* *}$ \\
\hline $\mathrm{pH}$ & - & - &,$- 787^{\star \star}$ &,$- 665^{\star}$ & ,414 &,$- 640^{*}$ & ,339 &, $621^{*}$ &,$- 619^{\star}$ &,$- 615^{\star}$ &, $592^{*}$ \\
\hline Shear Hardness & - & - & - &, $677^{\star}$ &,- 456 &, $873^{\star *}$ &,$- 610^{*}$ &,$- 782^{\star *}$ &, $852^{* *}$ &, $838^{\star *}$ &,$- 835^{\star *}$ \\
\hline Penetration Hardness & - & - & - & - &,$- 603^{*}$ & ,453 &,- 088 &,$- 658^{\star}$ & ,412 & ,418 &,$- 693^{*}$ \\
\hline Adhesiveness & - & - & - & - & - &,- 340 & ,417 &, $672^{*}$ &,- 284 &,- 267 &, 533 \\
\hline TPA Hardness & - & - & - & - & - & - &,- 485 &,$- 718^{\star *}$ &, $996^{* *}$ &, $993^{* *}$ &,$- 702^{\star}$ \\
\hline Springiness & - & - & - & - & - & - & - &, 539 &,- 457 &,- 410 & ,466 \\
\hline Cohesiveness & - & - & - & - & - & - & - & - &,$- 656^{*}$ &,$- 641^{\star}$ &, $789^{* *}$ \\
\hline Gumminess & - & - & - & - & - & - & - & - & - & ,999** &,$- 665^{\star}$ \\
\hline Chewiness & - & - & - & - & - & - & - & - & - & - &,$- 655^{\star}$ \\
\hline
\end{tabular}

Correlation is significant at the ${ }^{\star} 0.05$ level and ${ }^{* *} 0.01$ level (2-tailed). 
by the increase in the amount of light reflected by virtue of the increasing opacity of köftür samples. The increase in redness $\left(a^{*}\right)$ and yellowness $\left(b^{*}\right)$ values of samples could be due to the occurrence of browning reactions during preparations. There are two types of browning reactions in foods; enzymatic and non-enzymatic (caramelisation and the Maillard reaction). Non-enzymatic browning reactions are especially responsible for colour formation in heat treated food. Maillard reaction is occurred between a reducing sugar or polysaccharide with protein or peptide. This reaction could occur even during storage (Bassey et al., 2013) and it has maximum intensity in the range of 0.6 to $0.8 \mathrm{a}_{\mathrm{w}}$ (Bertrand et al., 2018). When considering the sugar from grapes and protein from wheat flour; the increase in redness and yellowness during storage (Table 1) can be attributed to the continued Maillard reaction.

\subsection{Textural properties of köftür samples}

The increase in shearing, penetration and TPA hardness values of köftür samples could be associated with starch retrogradation process (Table 2 and Table 3). Starch is widely used in food production as a thickener and texture stabilizer and it significantly contributes to the textural properties of foods (Singh et al., 2007). Therefore, changes in starch affect the textural properties of food system. The increase in hardness of starch-based foods usually attributed to the starch retrogradation. Göksel et al. (2013) and Yu et al. (2012) stated that the starch retrogradation contributed to the increase in hardness of starch gel during storage. The decrease in the adhesiveness value during the storage period could also be attributed to starch retrogradation (Table 2). Similar result was reported by Yu et al. (2012). Yu et al. (2009) stated that starch retrogradation contributes to increase of hardness and decrease of adhesiveness of cooked rice during storage.

Cohesiveness and resilience values of the köftür samples were slightly but significantly decreased as increasing storage time (Table 3). Cohesiveness is defined as the strength of the internal bonds that form the structure of the product (Nishinari \& Fang, 2018). Resilience is described as the ability of the sample returns to the original shape (Bourne, 2002). According to this, despite the decrease in cohesiveness and resilience values, it can be said that the köftür samples preserves its structural integrity and elasticity. The statistically insignificant change in springiness value can be considered as another indicator that the köftür samples maintain its elastic structure.

\section{Conclusions}

The findings showed that the slightly changes occurred in the tested quality criteria of the köftür samples during the storage period. Textural analysis showed that although some parameters were significantly changed during the changes, these changes were small; thus, it was concluded that the köftür preserves its textural properties during storage period. In future studies, the changes in nutritional value of köftür during storage can be examined.

\section{References}

Abba, H., Ibrahim, A., Shallangwa, G. A., Uba, S., \& Dallatu, Y. A. (2014). Effect of acetylation on stability to retrogradation of starch extracted from wild Polynesian Arrowroot (Tacca leontopetaloides (L.) Kuntze) for utilization as adhesive on paper. Journal of Polymers. 732174, 1-9. http://dx.doi.org/10.1155/2014/732174.
Ali, J., Pandey, S., Singh, V., \& Joshi, P. (2016). Effect of coating of aloe vera gelon shelf life of grapes. Current Research in Nutrition and Food Science, 4(1), 58-68. http://dx.doi.org/10.12944/CRNFSJ.4.1.08.

Alishahi, A., Farahnaky, A., Majzoobi, M., \& Blanchard, C. L. (2015). Physicochemical and textural properties of corn starch gels: Effect of mixing speed and time. Food Hydrocolloids, 45, 55-62. http:// dx.doi.org/10.1016/j.foodhyd.2014.11.005.

Bassey, F. I., Chinnan, M. S., Ebenso, E. E., Edem, C. A., \& Iwegbue, C. M. A. (2013). Colour change: An indicator of the extent of maillard browning reaction in food system. Asian Journal of Chemistry, 25(16), 9325-9328. http://dx.doi.org/10.14233/ajchem.2013.15504.

Bertrand, E., El Boustany, P., Faulds, C. B., \& Berdague, J. L. (2018). The maillard reaction in food: an introduction. In: G. W. Smithers (Ed.), Reference module in food science. Netherlands: Elsevier. https:// doi.org/10.1016/B978-0-08-100596-5.21459-5.

Bogracheva, T. Y., Wang, Y. L., Wang, T. L., \& Hedley, C. L. (2002). Structural studies of starches with different water contents. Biopolymers, 64(5), 268-281. http://dx.doi.org/10.1002/bip.10190. PMid:12115134.

Bourne, M. C. (2002). Food texture and viscosity: concept and measurement (2nd ed., p. 416). New York: Academic Press.

Food and Agriculture Organization - FAO. (2019). Rome: FAO. Retrieved from http://www.fao.org/faostat/en/\#data/QC

Geera, B. P., Nelson, J. E., Souza, E., \& Huber, K. C. (2006). Composition and properties of A- and B-type starch granules of wild-type, partial waxy, and waxy soft wheat. Cereal Chemistry, 83(5), 551-557. http:// dx.doi.org/10.1094/CC-83-0551.

Göksel, M., Doğan, M., Toker, O. S., Özgen, S., Sarığlu, K., \& Oral, R. A. (2013). The effect of starch concentration and temperature on grape molasses: Rheological and textural properties. Food and Bioprocess Technology, 6(1), 259-271. http://dx.doi.org/10.1007/ s11947-011-0705-5.

Horstmann, S. W., Lynch, K. M., \& Arendt, E. K. (2017). Starch characteristics linked to gluten-free products. Foods, 6(4), 29. http:// dx.doi.org/10.3390/foods6040029. PMid:28383504.

Nishinari, K., \& Fang, Y. (2018). Perception and measurement of food texture: Solid foods. Journal of Texture Studies, 49(2), 160-201. http:// dx.doi.org/10.1111/jtxs.12327. PMid:29437224.

Semerci, A., Kızıltuğ, T., Çelik, A. D., \& Kiracı, M. A. (2015). Türkiye Bağcılığının Genel Durumu. Journal of Agricultural Faculty of Mustafa Kemal University, 20(2), 42-51.

Singh, J., Kaur, L., \& McCarthy, O. J. (2007). Factors influencing the physico-chemical, morphological, thermal and rheological properties of some chemically modified starches for food applications: a review. Food Hydrocolloids, 21(1), 1-22. http://dx.doi.org/10.1016/j. foodhyd.2006.02.006.

Turkish Statistical Institute - TUIK. (2019). Çankaya, Ankara: TurkStat. Retrieved from http://www.turkstat.gov.tr

Vamadevan, V., \& Bertoft, E. (2018). Impact of different structural types of amylopectin on retrogradation. Food Hydrocolloids, 80, 88-96. http://dx.doi.org/10.1016/j.foodhyd.2018.01.029.

Wang, S., Li, C., Copeland, L., Niu, Q., \& Wang, S. (2015). Starch retrogradation: A comprehensive review. Comprehensive Reviews in Food Science and Food Safety, 14(5), 568-585. http://dx.doi. org/10.1111/1541-4337.12143.

Yu, S., Ma, Y., \& Sun, D. W. (2009). Impact of amylose content on starch retrogradation and texture of cooked milled rice during storage. Journal of Cereal Science, 50(2), 139-144. http://dx.doi. org/10.1016/j.jcs.2009.04.003.

Yu, S., Ma, Y., \& Zheng, X. Q. (2012). Effects of low- and ultralowtemperature freezing on retrogradation and textural properties of rice starch gel during storage. Journal of Texture Studies, 43(3), 175-186. http://dx.doi.org/10.1111/j.1745-4603.2011.00325.x. 